\title{
Nootropic Candidates Inhibit Head-Twitches Induced by Mescaline in Mice
}

\author{
Tsuneyuki Yamamoto, Masuo Ohno, Shin-ichi Yatsugi, Yasuhiro Fujikawa and Showa Ueki \\ Department of Pharmacology, Faculty of Pharmaceutical Sciences, Kyushu University 62, Fukuoka 812, Japan
}

Received February 14, 1992 Accepted April 27, 1992

\begin{abstract}
The effects of various nootropic candidates on mescaline-induced head-twitches were studied in mice. The number of head-twitches induced by mescaline $(100 \mathrm{mg} / \mathrm{kg}$, s.c.) was significantly reduced by idebenone (32 and $100 \mathrm{mg} / \mathrm{kg}$, i.p.), minaprine $(0.32-10 \mathrm{mg} / \mathrm{kg}$, p.o.) and nebracetam (100 $\mathrm{mg} / \mathrm{kg}$, p.o. $)$. Cholinesterase inhibitors such as tetrahydroaminoacridine ( 1 and $10 \mathrm{mg} / \mathrm{kg}$, p.o.), NIK247 (10 and $18 \mathrm{mg} / \mathrm{kg}$, p.o.) and physostigmine $(0.32 \mathrm{mg} / \mathrm{kg}$, i.p.) also suppressed the head-twitch response to mescaline. These results suggest that the direct or indirect cholinergic-activating effects of these drugs may be involved in inhibiting mescaline-induced head-twitches.
\end{abstract}

Keywords: Head-twitches, Nootropics, Acetylcholine

Hallucinogenic drugs and the serotonin (5-HT) precursor 5-hydroxytryptophan cause a characteristic headtwitch behavior in mice and rats, which is associated with hallucinogenic activity in humans $(1-3)$. It has been reported that the 5 -HT agonist mescaline-induced head-twitches are inhibited by various 5 -HT antagonists including the selective $5-\mathrm{HT}_{2}$ receptor antagonists ketanserin and pirenperone and that antagonism of mescaline correlates with inhibition of $\left[{ }^{3} \mathrm{H}\right]$ spiperone binding to the rat prefrontal cortex in vitro (4). These findings indicate that the head-twitches induced by mescaline are mediated by central $5-\mathrm{HT}_{2}$ receptors. Recently, 5-HT was found to inhibit the release of acetylcholine by activating $5-\mathrm{HT}_{2}$ receptors in the rat brain (5). Furthermore, the muscarinic receptor antagonist atropine can produce head-twitches in mice (1). Thus, it is likely that suppression of the cholinergic function may contributc to the appearance of mescaline-induced head-twitches. In this study, we investigated the effects of various nootropic candidates with cholinergicactivating actions on the head-twitches induced in mice by mescaline.

The animals used were male ddY strain mice $(20-35$ g) obtained from Nippon SLC. The mice were housed in a room maintained at a temperature of $23 \pm 2{ }^{\circ} \mathrm{C}$ with a 12-hr light-dark cycle (light period: 07:0019:00). Food and water were available ad libitum throughout the experiment.

The number of head-twitches was counted during the
$20 \mathrm{~min}$ period, starting $20 \mathrm{~min}$ after s.c.-injection of mescaline at $100 \mathrm{mg} / \mathrm{kg}$. For observation, the mice were placed in a transparent glass cylinder $(20 \mathrm{~cm}$ in height and $13 \mathrm{~cm}$ in inner diameter) immediately after the mescaline injection.

The drugs used were idebenone (Takeda Chemical Industries Ltd.), minaprine (Sanofi; Taisho Pharmaceutical Co., Ltd.), nebracetam (WEB 1881 FU, Nippon Boehringer Ingelheim), aniracetam (Nippon Roche), THA (tetrahydroaminoacridine hydrochloride, Aldrich), NIK-247 (Nikken Chemical Co., Ltd.), physostigmine salicylate (Sigma Chemical Co.) and mescaline hydrochloride. Idebenone and aniracetam were suspended in 5\% gum arabic and 1\% carboxymethylcellulose solution, respectively. Other drugs were dissolved in distilled water. Drugs were given p.o., except as noted, in a volume of $0.1 \mathrm{ml}$ per $10 \mathrm{~g}$ body weight. Idebenone, minaprine, nebracetam and aniracetam were given $20 \mathrm{~min}$ before the mescaline injection. The other drugs were given $10 \mathrm{~min}$ before mescaline. The statistical significance of the effects of the drugs on the number of head-twitches was determined by a one-way analysis of variance (ANOVA) followed by Dunnett's test.

Idebenone $(10-100 \mathrm{mg} / \mathrm{kg}$, i.p.) produced a dose-dependent reduction in the number of head-twitches induced by s.c. injection of $100 \mathrm{mg} / \mathrm{kg}$ mescaline $[\mathrm{F}(3$, $36)=14.6, P<0.01]$, an effect that reached significance for the 32 and $100 \mathrm{mg} / \mathrm{kg}$ doses (Table 1). The 
Table 1. Inhibition of mescaline-induced head-twitches by nootropic drugs in mice

\begin{tabular}{|c|c|c|c|c|}
\hline Drug & $\mathrm{mg} / \mathrm{kg}$ & Route & $\mathrm{N}$ & Number of head-twitches \\
\hline Control & - & - & 10) & $13.2 \pm 0.9$ \\
\hline \multirow[t]{3}{*}{ Idebenone } & 10.0 & i.p. & 10 & $11.6 \pm 1.4$ \\
\hline & 32.0 & i.p. & 10 & $6.7 \pm 0.8^{* *}$ \\
\hline & 100.0 & i.p. & 10 & $4.3 \pm 1.2^{* *}$ \\
\hline Control & - & - & 10 & $12.3 \pm 1.2$ \\
\hline \multirow{3}{*}{ Minaprine } & 0.32 & p.o. & 10 & $8.2 \pm 0.9^{*}$ \\
\hline & 1.0 & p.o. & 10 & $7.0 \pm 0.9^{* *}$ \\
\hline & 10.0 & p.o. & 10 & $3.9 \pm 1.0^{* *}$ \\
\hline \multirow[t]{2}{*}{ Nebracetam } & 32.0 & p.o. & 10 & $8.1 \pm 2.0$ \\
\hline & 100.0 & p.o. & 10 & $3.9 \pm 0.5^{* *}$ \\
\hline \multirow[t]{2}{*}{ Aniracetam } & 32.0 & p.o. & 10 & $7.1 \pm 1.2$ \\
\hline & 100.0 & p.o. & 10 & $7.9 \pm 2.4$ \\
\hline \multirow[t]{2}{*}{ THA } & 1.0 & p.o. & 10 & $7.9 \pm 1.3^{*}$ \\
\hline & 10.0 & p.o. & 10 & $3.9 \pm 0.6^{* *}$ \\
\hline Control & - & - & 10 & $17.1 \pm 1.9$ \\
\hline \multirow[t]{3}{*}{ NIK-247 } & 3.2 & p.o. & 10 & $13.4 \pm 1.4$ \\
\hline & 10.0 & p.o. & 10 & $9.1 \pm 2.0^{* *}$ \\
\hline & 18.0 & p.o. & 10 & $7.8 \pm 1.5^{* *}$ \\
\hline Control & - & - & 16 & $12.4 \pm 1.1$ \\
\hline \multirow[t]{2}{*}{ Physostigmine } & 0.1 & i.p. & 14 & $10.4 \pm 1.6$ \\
\hline & 0.32 & i.p. & 8 & $6.4 \pm 1.3^{*}$ \\
\hline
\end{tabular}

Head-twitches were counted during the $20 \mathrm{~min}$ period, starting $20 \mathrm{~min}$ after s.c.-injection of mescaline at $100 \mathrm{mg} / \mathrm{kg}$. Idebenone, minaprine, nebracetam and aniracetam were given $20 \mathrm{~min}$ before the mescaline injection. The other drugs were given $10 \mathrm{~min}$ before mescaline. Values are means $\pm S$.E. The significance of differences from the control group was determined by a one-way ANOVA followed by Dunnett's test. ${ }^{*} \mathrm{P}<0.05,{ }^{* *} \mathrm{P}<0.01$.

number of mescaline-induced head-twitches was also significantly reduced by minaprine at $0.32-10 \mathrm{mg} / \mathrm{kg}$ $[\mathrm{F}(3,36)=12.0, \mathrm{P}<0.01]$ and by the pyrrolidinone derivative nebracetam at $100 \mathrm{mg} / \mathrm{kg}[\mathrm{F}(2,27)=9.4, \mathrm{P}<$ $0.01]$. Aniracetam (32 and $100 \mathrm{mg} / \mathrm{kg}$ ) showed a tendency to inhibit the head-twitches. Cholinesterase inhibitors such as THA at 1 and $10 \mathrm{mg} / \mathrm{kg}[\mathrm{F}(2,27)=$ $15.1, \mathrm{P}<0.01], \mathrm{NIK}-247$ at 10 and $18 \mathrm{mg} / \mathrm{kg}[\mathrm{F}(3,36)$ $=6.0, \mathrm{P}<0.01]$ and physostigmine at $0.32 \mathrm{mg} / \mathrm{kg}$, i.p. $[F(2,35)=4.0, P<0.05]$ also decreased the number of head-twitches induced by mescaline.

In this study, the head-twitches induced by mescaline were inhibited by cholinesterase inhibitors such as THA, NIK-247 and physostigmine $(6,7)$. Minaprine and nebracetam have been shown to act as agonists at $\mathrm{M}_{1}$-muscarinic receptors in the rat brain $(8,9)$ and to reverse scopolamine-induced memory deficits in rats $(10,11)$. Results of behavioral tests indicate that idebenone also has some cholinergic-activating action (12). Thus, the direct and indirect cholinergic-activating actions of the nootropic candidates examined in this study may play a role in inhibiting mescaline-induced head-twitches. On the other hand, cortical cholinergic activity decreases in senile dementia, and the reduction in choline acetyltransferase in the parietal and temporal cortex is more severe in patients with hallucinations than in those without them (13). This finding indicates that lowering of cerebral cholinergic activity is related to the incidence of hallucinations in patients with senile dementia. The present results showing that mescalineinduced head-twitches were inhibited by various nootropic candidates with cholinergic-activating actions suggest the efficacy of these drugs for the hallucinations/delusions that occur in patients with senile dementia.

\section{Acknowledgments}

We wish to thank Nikken Chemical Co., Ltd., Nippon Boehringer Ingelheim, Nippon Roche, Taisho Pharmaceutical Co., Ltd. and Takeda Chemical Industries Ltd. for providing the generous supplies of the drugs used in this study.

\section{REFERENCES}

1 Corne, S.J. and Pickering, R.W.: A possible correlation between drug-induced hallucinations in man and a behavioural response in mice. Psychopharmacologia (Berlin) 11, 65-78 (1967)

2 Corne, S.J., Pickering, R.W. and Warner, B.T.: A method for assessing the effects of drugs on the central actions of 5 hydroxytryptamine. Br. J. Pharmacol. 20, 106-120 (1963)

3 Yamamoto, T. and Ueki, S.: The role of central serotonergic mechanisms on head-twitch and backward locomotion in duced by hallucinogenic drugs. Pharmacol. Biochem. Behav. 14, $89-95$ (1981)

4 Niemegeers, C.J.E., Colpaert, F.C., Leysen, J.E., Awouters, F. and Janssen, P.A.J.: Mescaline-induced head-twitches in the rat: an in vivo method to evaluate serotonin $S_{2}$ antagonists. Drug Dev. Res. 3, 123 - 135 (1983)

5 Muramatsu, M., Tamaki-Ohashi, J., Usuki, C., Araki, H. and Aihara, H.: Serotonin-2 receptor-mediated regulation of release of acetylcholine by minaprine in cholinergic nerve terminal of hippocampus of rat. Neuropharmacology 27, 603609 (1988)

6 Ishii, Y. and Sumi, T.: Evaluation of a cholinomimetic drug, 9-amino-2,3,5,6,7,8-hexahydro-1 $\mathrm{H}$-cyclopenta $[b]$ quinoline (NIK-247), as an enhancer of endogenous efflux of acetylcholine from brain slices. Neuropharmacology 31, 61-66 (1992)

7 Shibanoki, S., Ishii, Y., Kubo, T., Kogure, M., Asai, S. and Ishikawa, $\mathrm{K}$ : Effects of 9-amino-2,3,5,6,7,8-hexahydro- $1 H$ cyclopenta-(b)-quinoline monohydrate hydrochloride (NIK 247) on cholinergic enzyme activity in rats. Pharmacol. Biochem. Behav. 39, 499-502 (1991)

8 Worms, P., Kan, J.-P., Steinberg, R., Terranova, J.-P., Perio, A. and Biziere, K.: Cholinomimetic activities of minaprine. Naunyn Schmiedebergs Arch. Pharmacol. 340, $411-418$ (1989)

9 Kitamura, Y., Hayashi, S. and Nomura, Y.: Effects of WEB $1881 \mathrm{FU}$, a novel nootropic, on cholinergic and adrenergic re- 
ceptors in the rat brain: action on $\mathbf{M}_{1}$-muscarinic receptors. Japan. J. Pharmacol. 52, 597-607 (1990)

10 Yamamoto, T., Yatsugi, S., Ohno, M., Furuya, Y., Kitajima, I. and Ueki, S.: Minaprine improves impairment of working memory induced by scopolamine and cerebral ischemia in rats. Psychopharmacology (Berlin) 100, 316-322 (1990)

11 Ohno, M., Yamamoto, T., Kitajima, I. and Ueki, S.: WEB $1881 \mathrm{FU}$ ameliorates impairment of working memory induced by scopolamine and cerebral ischemia in the three-panel run- way task. Japan. J. Pharmacol. 54, 53-60 (1990)

12 Yamazaki, N., Nagaoka, A. and Nagawa, Y.: Effect of idebenone on scopolamine-induced impairment of short-term memory in rats. Japan. J. Psychopharmacol. 5, 321-328 (1985) (Abs. in English)

13 Perry, E.K., Kerwin, J., Perry, R.H., Irving, D., Blessed G. and Fairbairn, A.: Cerebral cholinergic activity is related to the incidence of visual hallucinations in senile dementia of Lewy body type. Dementia 1, 2-4 (1990) 